\title{
Het particulier beroep tot nietigverklaring en het Montessori-arrest
}

\author{
Prof. mr. R. Barents*
}

Bij het Verdrag van Lissabon (2009) is in de vierde alinea van artikel 263 VWEU een derde zinsnede ingevoegd, op grond waarvan een particulier beroep kan instellen tegen 'regelgevingshandelingen die geen uitvoeringsmaatregelen met zich meebrengen'. In het op 6 november 2018 gewezen arrest in de gevoegde zaken C-622/16 t/m C-624/16 P, Montessori e.a./Commissie e.a., ECLI:EU:C:2018:873 heeft het Hof van Justitie geoordeeld dat het begrip 'regelgevingshandeling' betrekking heeft op 'alle niet-wetgevingshandelingen van algemene strekking'. Daaronder vallen ook besluiten van de Commissie over nationale steunregelingen. Met dit arrest is een bijna tien jaar durende zoektocht naar de strekking van dit begrip voorlopig afgesloten. In deze bijdrage worden de achtergronden en gevolgen van deze uitspraak nader toegelicht.

Hvf 6 november 2018, gevoegde zaken C-622/16 t/m C-624/16 P, Montessori e.a./Commissie e.a., ECLI:EU: $C: 2018: 873$.

\section{Artikel 263, vierde alinea, tweede en derde zinsnede VWEU}

Voor het beroep tot nietigverklaring van handelingen van de Unie maakt artikel 263 VWEU een onderscheid tussen geprivilegieerde en gewone beroepsgerechtigden. De eerste groep, aangeduid in de eerste alinea, omvat lidstaten en bepaalde instellingen, de laatstgenoemde groep alle natuurlijke en rechtspersonen ('particulieren'). Geprivilegieerde beroepsgerechtigden kunnen beroep instellen tegen alle handelingen van de Unie die rechtsgevolgen hebben, ongeacht of die handelingen tot hen zijn gericht. De vierde alinea van deze bepaling onderwerpt het particuliere beroep tot nietigverklaring

Prof. mr. R. (René) Barents is rechter in het Gerecht van de EU. Dit artikel is op persoonlijke titel geschreven. van handelingen van de Unie aan twee specifieke ontvankelijkheidsvoorwaarden. De eerste is het ongeschreven, door de rechtspraak uit het algemene bestuursrecht van de Unie afgeleide vereiste dat een particulier moet kunnen aantonen dat het beroep voor hem een belang heeft, kort gezegd, dat de nietigverklaring van de aangevochten handeling de klager een concreet voordeel kan

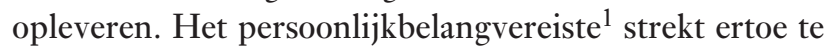
voorkomen dat de particulier zich opstelt als hoeder van het algemeen belang. Deze ontvankelijkheidsvoorwaarde, waarover veel rechtspraak bestaat, blijft hier buiten beschouwing.

De tweede specifieke ontvankelijkheidsvoorwaarde houdt een beperking in van de handelingen van de Unie die kunnen worden aangevochten. ${ }^{2}$ Particulieren kunnen alleen beroep tot nietigverklaring instellen ${ }^{3}$ tegen (1) handelingen die tot hen zijn gericht en (2) handelingen die hen rechtstreeks en individueel raken (vierde alinea, tweede zinsnede). Het eerste geval betreft een individuele handeling ('beschikking'), waardoor de auteur van die handeling (een instelling of andere entiteit van de Unie) de rechtspositie van de particulier(en) tot wie die handeling is gericht verandert (vergunning, ontheffing, subsidie, heffing, sanctie, enzovoort). In het tweede geval gaat het om individuele handelingen die ook gevolgen hebben voor een derde (goedkeuring steunmaatregel of concentratie waartegen een andere onderneming opkomt, enzovoort) en om handelingen van algemene strekking ('normatieve' of 'wetgevende' handelingen), zoals verordeningen, richtlijnen en algemene besluiten.

Met betrekking tot het vereiste van individueel raken is, sinds het Verdrag van Lissabon (2009), door de derde zinsnede van artikel 263, vierde alinea VWEU, voorzien in een uitzondering. Tegen wat 'regelgevende handelingen' wordt genoemd, kan een particulier beroep tot nietigverklaring instellen als deze (1) hem rechtstreeks

1. Procesbelang ('intérêt à agir'). Dit is niet hetzelfde als 'belanghebbende'.

2. Het begrip voor beroep vatbare handeling blijft hier buiten beschouwing.

3. Actieve procesbevoegdheid ('qualité d'agir'). 
raken en (2) geen uitvoeringsmaatregelen met zich meebrengen. Voor die regelgevende handelingen geldt het vereiste van 'individueel' raken dus niet.

Waar komt deze ingewikkelde bepaling op neer? Aan het beroep tot nietigverklaring ligt het onderscheid tussen handelingen van algemene strekking (wetgeving, regelgeving) en individuele handelingen ten grondslag. Algemene handelingen zijn voor particulieren niet of slechts uitzonderlijk aanvechtbaar. De achtergrond van dit onderscheid is de overweging dat wetgevende maatregelen (vooral in formele zin) een uiting zijn van het zich via de wetgever manifesterende soevereine volk en dat de slagkracht van de wetgever niet belemmerd kan worden door handelen van particulieren. Dergelijke onderscheidingen vindt men in meer of mindere mate in alle continentale lidstaten. Het gaat daarbij overigens om een politiek gemotiveerd onderscheid; of het gerechtvaardigd is vanuit het oogpunt van individuele rechtsbescherming is een geheel ander punt.

De vierde alinea van artikel 263 VWEU is gebaseerd op het beginsel dat een handeling van de Unie voor een particulier pas aanvechtbaar is als hij daardoor wordt 'geindividualiseerd'. In het geval van een tot een particulier gerichte handeling is aan die eis per definitie voldaan, in andere gevallen (besluiten die ook derden betreffen en algemene handelingen) moet de particulier aantonen dat hij door die handelingen rechtstreeks en individueel is geraakt.

Het doel van het vereiste rechtstreeks raken is de omvang van het particuliere beroepsrecht te beperken tot gevallen waarin de bestreden handeling van de Unie rechtstreeks in de rechtspositie van de particulier ingrijpt, zonder dat daarvoor nog andere maatregelen moeten worden getroffen, door de Unie of door de lidstaten. De gedachte daarachter is dat als uitvoeringsmaatregelen nodig zijn, rechtsbescherming verkregen kan worden door tegen die maatregelen beroep in te stellen. Bij uitvoeringsmaatregelen van de Unie is dat het Gerecht, bij nationale uitvoeringsmaatregelen de nationale rechter. Het vereiste van rechtstreeks raken hangt vooral samen met de bevoegdheidsverdeling tussen de Unierechter en de nationale rechter.

De functie van het vereiste individueel raken is maatregelen van algemene strekking (verordeningen, richtlijnen en algemene besluiten) van het beroep tot nietigverklaring uit te sluiten, maar de particulier wel te beschermen tegen gevallen waarin een verordening in wezen neerkomt op een individueel besluit. ${ }^{4}$

\section{Raken in objectieve zin en individueel raken}

Het juridische onderscheid tussen handelingen van algemene strekking (waartegen geen particulier beroep openstaat) en individualiserende handelingen wordt

4. HvJ 16 juni 1970, zaak C-69/69, Alcan, ECLI:EU:C:1970:53, punt 4 gevormd door de wijze waarop een particulier door een handeling 'geraakt' wordt. Zoals blijkt uit de Franse tekst van artikel 263 VWEU ('concerner') is deze term hetzelfde als 'betreffen'. Een particulier wordt door een handeling van algemene strekking 'geraakt' als zijn situatie voldoet aan de voorwaarden die deze handeling stelt voor het intreden van de rechtsgevolgen daarvan. Dit 'raken' is het kenmerk van iedere algemeen verbindende regeling, dat wil zeggen 'een maatregel van algemene strekking die van toepassing is op objectief omschreven situaties, die voor algemene en in abstracto omschreven categorieën van personen tot rechtsgevolgen leidt', aldus de klassieke formule uit de rechtspraak.

'Raken' in deze zin is niet hetzelfde als 'individueel raken'. Het verschil tussen beide vormen van raken is gelegen in de hoedanigheid van de particulier. Een handeling is ten opzichte van een particulier te beschouwen als een handeling van algemene strekking als deze daardoor wordt geraakt in een objectieve hoedanigheid. Dat is het geval als die handeling een 'open kring' van personen betreft, in die zin dat eenieder die nu of in de toekomst aan de objectief omschreven voorwaarden voldoet, met de rechtsgevolgen van die handeling te maken krijgt. ${ }^{6}$ Van objectief omschreven voorwaarden is sprake als voor de werkingssfeer van een regeling wordt aanknoopt bij een bepaalde handeling ('producenten van...', 'invoer van...', 'uitstoot van', enzovoort). ${ }^{7}$

Om te bepalen of men door een maatregel op objectieve wijze wordt geraakt, moet een vergelijking worden gemaakt tussen de situatie van de betrokken particulier en alle andere personen die met die rechtsgevolgen van die regeling geconfronteerd worden. ${ }^{8}$ Blijkt dat de particulier door die regeling geraakt wordt op grond van een hoedanigheid die hij met alle andere personen gemeen heeft, dan wordt hij geraakt op objectieve wijze en niet op individuele wijze. Dat men behoort tot de categorie van particulieren die in de regeling is omschreven, daardoor in zijn belangen kan worden geraakt, schade kan ondervinden, heffingen moet betalen of niet voor subsidies in aanmerking komt, met sancties kan worden geconfronteerd, zijn daarom allemaal argumenten die alleen bevestigen dat men 'geraakt' wordt, maar niet 'individueel geraakt' wordt. Het gevolg is dat het overgrote deel van particuliere beroepen tot nietigverklaring van regelingen van algemene strekking eindigt in een beschikking van niet-ontvankelijkheid.

Uit het voorgaande blijkt al dat 'individueel raken' een uitzonderlijke situatie is. Dat blijkt ook uit de aloude Plaumann-formule, die op abstracte wijze beschrijft wanneer daarvan sprake is. Een particulier wordt door

5. Constante omschrijving sinds HvJ 11 juli 1968, zaak C-6/68, Zuckerfabrik Watenstedt, ECLI:EU:C:1968:43.

6. Zie voor een recent voorbeeld HvJ 24 november 2016, gevoegde zaken C-408/15 P en C-409/15 P, Ackermann Saatsucht e.a./Parlement en Raad, ECLI:EU:C:2016:893, punten 39-40.

7. Voor een goed voorbeeld, zie Gerecht 24 januari 2001, gevoegde zaken T-112/00 en T-122/00, Iberotam e.a./Commissie, ECLI:EU:T:2001:20, punt 61 .

8. Zie o.m. HvJ 11 februari 1999, zaak C-390/95 P, ARM/Commissie, ECLI:EU:C:1999:66, punt 28 en HvJ 30 maart 2004, zaak C-167/02 P, Rothley e.a./Parlement, ECLI:EU:C:2004:193, punt 36. 
een handeling individueel geraakt als die 'hem treft uit hoofde van bepaalde bijzondere hoedanigheden of van een feitelijke situatie die hem ten opzichte van ieder ander karakteriseert'. ${ }^{9}$ Uit deze formule blijkt dat de betrokken maatregel de particulier betreft op een wijze die verschilt van die waarop andere particulieren worden geraakt: door de inhoud van de maatregel of door bijzondere omstandigheden en kenmerken van zijn situatie wordt de particulier op specifieke wijze geraakt. Het is aan de klager om argumenten aan te voeren waaruit blijkt dat hij met betrekking tot die maatregelen in een 'bijzondere' positie verkeert, aldus het Gerecht. ${ }^{10}$ In het overgrote deel van die gevallen is er sprake van een 'gesloten groep', dat wil zeggen een kring van particulieren die door hun hoedanigheid of door andere omstandigheden gefixeerd is en niet meer toegankelijk is voor anderen.

Het verschil tussen objectief en individueel raken is overigens subtiel. In veel gevallen waarin de Unie een handeling van algemene strekking aanneemt gaat het om een specifieke interventie in het sociaaleconomisch leven. Het is niet uitgesloten dat in een dergelijk geval het aantal ondernemingen dat daardoor getroffen wordt, kan worden bepaald (bijvoorbeeld importeurs van een bepaald product). Zelfs is het niet uitgesloten dat een maatregel in werkelijkheid slechts enkele of zelfs één onderneming treft. ${ }^{11}$ Toch is er in die gevallen geen sprake van een gesloten groep omdat ook (in theorie) toekomstige importeurs met die maatregel te maken kunnen krijgen. ${ }^{12}$

Een gesloten groep kan tot stand komen doordat de maatregelen lijsten van namen of producten bevatten (quotaregelingen, ${ }^{13}$ beperkende maatregelen tegen met name genoemde personen, ${ }^{14}$ lijsten van vissersboten, ${ }^{15}$ gevaarlijke stoffen, ${ }^{16}$ enzovoort), voorzien in bepaalde zorgplichten (rekening houden met reeds gesloten contracten) ${ }^{17}$ en procedurele rechten (klachtprocedures, consultatieplichten). Een andere categorie van individueel raken vormt de zogenoemde Codorniu-clausule, op grond waarvan een bepaling van algemene aard toch geacht wordt een particulier individueel te raken op grond van zeer specifieke omstandigheden (verkregen

9. HvJ 15 juli 1963, zaak C-25/62, Plaumann/Commissie, ECLI:EU:C 1963:17.

10. Gerecht 27 juli 2018, zaak T-101/17, Apple Distribution International/ Commissie, ECLI:EU:T:2018:505, punt 26.

11. HvJ 29 januari 1985, zaak C-147/83, Binderer/Commissie, ECLI:EU:C: 1985:26, punt 31; HvJ 15 februari 1996, zaak C-209/94 P, Buralux/ Raad, ECLI:EU:C:1996:54, punt 29; Gerecht 29 januari 2002, zaak T-47/00, Rica Food/Commissie, ECLI:EU:T:2002:7, punten 38-39.

12. Zie o.m. Gerecht 28 september 2011, zaak T-96/09, UCAPT/Raad, ECLI:EU:T:2011:542, punten 40-41.

13. HvJ 29 oktober 1980, zaak C-138/79, Roquette/Raad, ECLI:EU:C 1980:249, punten 15-16.

14. Gerecht 6 september 2013, gevoegde zaken T-4/11 en T-5/11, Export Development Bank of Iran/Raad, ECLI:EU:T:2013:400, punt 37.

15. HvJ 26 april 1988, zaak C-207/86, Apesco/Commissie, ECLI:EU:C: 1988:200, punt 12 .

16. Gerecht 3 september 2009, zaak T-327/07, Cheminova e.a./ Commissie, ECLI:EU:T:2011:300, punt 66.

17. HvJ 17 januari 1985, zaak C-11/82, Piraiki-Patraiki/Commissie, ECLI:EU:C:1985:18, punten 28-31. individuele rechten). ${ }^{18}$ Omdat de Plaumann-formule moeilijk op meer specifieke wijze omschreven kan worden, is de rechtspraak over het begrip individueel raken' sterk casuïstisch van aard, tot uiting komend in naar tijd en onderwerp (zoals landbouw, staatsteun, concurrentie, externe handel, ondernemersverenigingen) uiteenlopende benaderingen.

Samenvattend kan men stellen dat door het vereiste van 'individueel raken' krachtens de tweede zinsnede van artikel 263, vierde alinea VWEU, een particulier slechts bij wijze van uitzondering toegang tot de Unierechter vindt met een beroep tot nietigverklaring van een handeling van algemene strekking. Van de ruim vijftienhonderd uitspraken over deze materie in de afgelopen halve eeuw kon deze barrière slechts door ongeveer vijftig justitiabelen met succes worden genomen. ${ }^{19}$

\section{De uitbreiding van het particuliere beroep tot nietigverklaring door het Verdrag van Lissabon}

\section{Effectieve rechtsbescherming}

Sinds de jaren zeventig van de vorige eeuw wordt in de meerderheid van de zeer omvangrijke literatuur over artikel $263 \mathrm{VWEU}$ het standpunt gehuldigd dat gezien in het licht van het beginsel van effectieve rechtsbescherming de uitlegging van het vereiste 'individueel raken' te restrictief is. ${ }^{20}$ De premisse die daaraan ten grondslag ligt, is dat de particulier over een zelfstandig recht dient te beschikken om regelingen van algemene strekking van de Unie die betrekking hebben op zijn situatie, aan rechtmatigheidscontrole door de rechter te onderwerpen. Anders gesteld, het grote verschil tussen 'raken' en 'individueel raken' moet worden afgezwakt of zelfs geheel worden weggenomen. ${ }^{21}$ Veelal steunt deze premisse op twee overwegingen. De eerste is dat volgens de rechtspraak artikel 6 EVRM een integraal onderdeel van het Unierecht vormt en daarom de klassieke uitlegging van 'individueel raken' niet gehandhaafd kan worden. De tweede overweging is dat voor de nationale rechter particulieren geen recht geldend kunnen maken op het stellen van prejudiciële vragen over de rechtma-

18. HvJ 18 mei 1994, zaak C-309/89, Codorniu/Raad, ECLI:EU:C 1994:197.

19. Zie uitvoerig over het vereiste van individueel raken R. Barents, Remedies and Procedures before the EU Courts, Den Haag: Wolters Kluwer 2016, hfdst. 6.

20. Zie reeds A. Barav, 'Direct and individual concern: an almost insurmountable barrier to the admissibility of individual appeal to the EEC Court', Common Market Law Review 1974, nr. 2, p. 191-198, op p. 191.

21. Zie N. Hipp, 'La notion de "mesure d'execution" au sens de l'article 263, alinea 4, TFUE et l'exemple du contentieux des aides d'Etat', Revista Romana de Drept European 2013, nr. 3, p. 37-48, op p. 48. 
tigheid van een Uniemaatregel van algemene strekking. ${ }^{22}$

Beide overwegingen zijn overigens kwestieus. De tekst noch de rechtspraak over artikel 6 EVRM (en thans art. 47 Handvest) vereist dat de particulier over een algemeen beroepsrecht tegen wetgeving moet beschikken. Voor wat betreft de prejudiciële procedure geldt dat de nationale rechter verplicht is, als hij twijfelt aan de geldigheid van een maatregel van de Unie, het Hof van Justitie om een uitspraak te verzoeken. Dat de nationale rechter wiens beslissingen niet vatbaar zijn voor hogere voorziening die plicht niet altijd nakomt, is als zodanig nog geen reden om de werkingssfeer van het particuliere beroepsrecht onder artikel 263, vierde alinea, VWEU uit te breiden. Het afzwakken of wegnemen van de voorwaarde van individueel raken heeft tot gevolg dat de Unierechter bevoegd zou worden zich uit te spreken over de rechtmatigheid van alle handelingen van de Unie van algemene strekking waardoor een particulier geraakt wordt. Dit zou feitelijk inhouden dat de Unierechter een federale rechter wordt, wat neerkomt op een miskenning dat het rechtspraaksysteem van de Unie een gedecentraliseerd karakter heeft, in het kader waarvan de nationale rechter functioneert als gewone rechter van de Unie. ${ }^{23}$

Hoe dat ook zij, het Hof van Justitie heeft zijn Plaumann-rechtspraak nooit wezenlijk veranderd. Het argument dat het vereiste van individueel raken in strijd zou zijn met het beginsel van effectieve rechtsbescherming wordt door de Unierechter systematisch afgewezen. ${ }^{24}$ Daarmee is overigens niet gezegd dat het systeem van geldigheidstoetsing van normatieve handelingen door middel van door de nationale rechter gestelde prejudiciele vragen optimaal is. Het is bijvoorbeeld altijd mogelijk dat op nationaal niveau geen beroepsweg voorhanden is. Weliswaar zijn de lidstaten op grond van verplichting tot loyale samenwerking gehouden in rechtsbeschermingsmechanismen te voorzien - dit is thans neergelegd in artikel 19 lid $1 \mathrm{VEU}$ - maar een lacune kan nooit worden uitgesloten. Belangrijker is het geval waarin een algemene regeling van de Unie geen nationale uitvoeringsmaatregelen vereist. Het bekende voorbeeld uit de rechtspraak is het verbod van het gebruik van bepaalde typen visnetten. In een dergelijk geval is geen uitvoeringsmaatregel vereist; voldoende is dat de lidstaat dat Unierechtelijke verbod handhaaft. Rechtsbescherming kan in een dergelijk geval alleen worden verkregen door het betrokken verbod te overtreden en in een beroep tegen de sanctie de onrechtmatigheid van dat verbod in te roepen. Twijfelt de nationale rechter aan de rechtmatigheid van dat verbod, dan is hij verplicht ter zake een prejudiciële geldigheidsvraag aan het Hof van Justitie te stellen. Het verkrijgen van rechtsbescherming door het overtreden van een rechtsregel is echter kwestieus.

\section{Het Verdrag van Lissabon}

Het aloude debat over de uitlegging van het vereiste van individueel raken onderging een opleving toen in 2000 het Handvest voor de grondrechten van de Unie werd opgesteld, dat in artikel 47 voorziet in het recht op effectieve rechtsbescherming. De laatstgenoemde bepaling vormde de achtergrond waartegen de Europese Conventie (2002-2003) zich boog over de vraag of (toen) artikel 230, vierde alinea, EG-Verdrag gewijzigd zou moeten worden. ${ }^{25}$ Dit alles vormde voor het (toen nog) Gerecht van eerste aanleg aanleiding om in een arrest van 3 mei $2002^{26}$ een geheel nieuwe interpretatie te geven, waarvan de strekking in wezen was de voorwaarde van 'individueel' raken van zijn inhoud te ontdoen. Deze 'revolutie' was echter geen lang leven beschoren. ${ }^{27}$ Drie maanden later werd door het Hof van Justitie in hogere voorziening in een andere zaak de uitspraak van het Gerecht in barse bewoordingen ongedaan gemaakt. ${ }^{28}$ Wijziging van de ontvankelijkheidsvoorwaarden van het particuliere beroep is een exclusieve aangelegenheid van de verdragsgever. Overwegingen ontleend aan het beginsel van effectieve rechtsbescherming kunnen voor de Unierechter geen rechtvaardiging opleveren om de genoemde ontvankelijkheidsvoorwaarden op een coulantere wijze uit te leggen. Deze uitlegging van het vereiste van individueel raken is tot op heden gehandhaafd.

De Europese Conventie was over de vraag naar de wijziging van de vierde alinea van artikel 230 EG-Verdrag overigens sterk verdeeld. Consensus kon alleen worden bereikt over een voorstel om aan de vierde alinea de clausule 'alsmede tegen regelgevingshandelingen die hem rechtstreeks raken en die geen uitvoeringsmaatregelen met zich meebrengen' toe te voegen. De aldus in de Europese Grondwet aangepaste bepaling is door de verdragsgever in Lissabon overgenomen.
22. Voor een goed overzicht van de argumenten pro en contra zie de discussie tussen P. Nihoul, 'La recevabilité des recours en annulation introduits par un particulier à l'encontre d'un acte EU de portée générale', Revue trimestrielle de droit européen 1994, p. 171 en D. Waelbroeck en D. Verheyden, 'Les conditions de recevabilité du recours en annulation des particuliers contre les actes normatifs', Cahiers de droit européen 1995, nr. 3-4, p. 399-441, op p. 399.

23. Zie o.m. HvJ 28 april 2015, zaak C-456/13 P, T \& L Sugars en Sidul Açúcares/Commissie, ECLI:EU:C:2015:284, punten 49-50; HvJ 13 maart 2018, zaak C-244/16 P, IQV/Commissie, ECLI:EU:C: 2018:177, punt 43 .

24. Zie recent nog eens HvJ 17 mei 2018, zaak C-402/17 P, JYSK/ Commissie, ECLI:EU:C:2018:329, punt 24.
25. Zie uitgebreider R. Barents, Een Grondwet voor Europa. Achtergronden en commentaar, Deventer: Kluwer 2005, hfdst. 16.

26. Gerecht 3 mei 2002, zaak T-177/01, Jégo-Quéré/Commissie, ECLI:EU:T:2002:112.

27. Zie voor meer gegevens R. Barents, 'Een midzomernachtsdroom op de Kirchberg', SEW 2003, nr. 1, p. 2-9.

28. HvJ 25 juli 2002, zaak C-50/00 P, UPA/Raad, ECLI:EU:C:2002:462, punten 44-45. 


\section{Wetgevingshandelingen en niet-wetgevingshandelingen}

\section{De nieuwe nomenclatuur van handelingen van de Unie}

De grote vraag is uiteraard wat verstaan moet worden onder een 'regelgevende' handeling. Het VWEU omschrijft dit begrip niet. Duidelijk is wel dat het adjectief 'regelgevende' een beperking inhoudt van de onder artikel 263, vierde alinea, VWEU voor beroep vatbare handelingen. 'Regels geven' wijst in de richting van een handeling van algemene strekking. Toch kunnen niet alle handelingen van algemene strekking als regelgevende handelingen worden opgevat omdat anders een algemeen beroepsrecht tegen de eerstgenoemde categorie zou openstaan, met als gevolg dat de beperking van het particuliere beroepsrecht van de vierde alinea van artikel $263 \mathrm{VWEU}$ zijn betekenis verliest. Het gaat dus om een subcategorie van handelingen van algemene strekking die van het vereiste van individueel raken is verlost.

Sinds het Verdrag van Lissabon vallen handelingen van algemene strekking uiteen in twee groepen: wetgevingshandelingen en niet-wetgevingshandelingen. De wetgevingshandelingen worden aangenomen via een vaststellingsprocedure waarbij het Europees Parlement is betrokken (art. 289 VWEU). Ook deze groep valt weer uiteen in twee categorieën: 'gewone' wetgevingshandelingen, waarbij het Parlement optreedt als mederegelgever en 'bijzondere' wetgevingshandelingen, waarbij het Parlement een procedureel recht heeft (consultatie, toestemming).

Uit de travaux préparatoires van de Europese Conventie heeft het Hof van Justitie afgeleid dat wetgevingshandelingen ('gewone' en 'bijzondere') geen regelgevende handelingen kunnen vormen. ${ }^{29}$ Over deze conclusie worden verderop in dit artikel nog enkele opmerkingen gemaakt. Het gevolg is dat het begrip 'regelgevende' handelingen alleen betrekking kan hebben op alle nietwetgevingshandelingen van algemene strekking of bepaalde vormen daarvan. ${ }^{30}$ Het is die uitleggingsvraag die in het Montessori-arrest is beantwoord.

\section{Het Montessori-arrest}

De aanzet van de uitlegging van het begrip regelgevende handeling in het Montessori-arrest wordt gevormd door de zaken Woonlinie en Woonpunt, twee Nederlandse

29. Zie o.m. HvJ 3 oktober 2013, zaak C-583/11 P, Inuit Tapiriit Kanatam e.a./Parlement en Raad, ECLI:EU:C:2013:625, punt 61. Voor kritiek op deze uitspraak, zie D. Waelbroeck en T. Bombois, 'Des requérants “privilégiés" et des autres.... A propos de l'arrêt Inuit et de l'exigence de protection juridictionnelle effective des particuliers en droit européen', in: S. Mahieu (red.), Contentieux de I'Union européenne: questions choisies, Brussel: Larcier 2015, p. 22.

30. Zie uitvoerig W. Cremer, 'Der EuGH bleibt sich treu - Die Nichtigkeitsklage Privater 50 Jahre nach PLaumann', Zeitschrift für Gesetzgebung $2014,83$. woningcorporaties. ${ }^{31} \mathrm{Na}$ langdurige onderhandelingen had Nederland met de Commissie afspraken gemaakt over het aanpassen van een steunregeling voor stadsvernieuwing, met als gevolg dat de voorwaarden voor steun aan woningcorporaties minder gunstig werden dan voorheen. De corporaties stelden tegen het besluit van de Commissie beroep tot nietigverklaring in. Het Gerecht verklaarde beide beroepen niet-ontvankelijk omdat er niet was voldaan aan de voorwaarde van individueel raken. Volgens vaste rechtspraak kan een particulier geen beroep instellen tegen een handeling van algemene strekking - zoals een besluit waarbij een sectorale steunregeling wordt verboden of voorwaardelijk wordt goedgekeurd - omdat de betrokkenen worden geraakt op objectieve wijze, zoals elke marktdeelnemer die zich feitelijk of potentieel in een identieke situatie bevindt. ${ }^{32}$ Het argument dat de groep van woningcorporaties ten tijde van het besluit van de Commissie een gesloten kring vormde, werd terzijde gesteld. ${ }^{33}$

In hogere voorziening werden deze niet-ontvankelijkheidsbeschikkingen nietig verklaard. ${ }^{34}$ De nietigverklaring vloeide voort uit de volgens het Hof van Justitie onterechte afwijzing van het argument over de gesloten kring. Het effect van het besluit was weliswaar dat de nieuwe, minder gunstige, steunregeling op alle bestaande en toekomstige corporaties van toepassing werd, maar dat alleen de eerstgenoemde groep een wijziging in zijn rechtpositie onderging door de gewijzigde steunregeling en dat daarom die corporaties, als gesloten groep, individueel werden geraakt. ${ }^{35}$ Aldus illustreren deze arresten nog eens hoe subtiel het onderscheid tussen de begrippen 'open' en 'gesloten' kring kan zijn.

Het voorgaande heeft betrekking op de figuur van rechtstreeks en individueel raken. Of het besluit van de Commissie als een regelgevende handeling kon worden aangemerkt, had het Gerecht niet onderzocht. Die mogelijkheid was door de corporaties ook niet aangevoerd. Het Hof van Justitie was echter van oordeel dat het Gerecht dit wel had moeten doen omdat de daarop betrekking hebbende voorwaarden 'minder streng' zijn. ${ }^{36}$ Het Gerecht moet dus voortaan ambtshalve onderzoeken of een aangevochten handeling als een 'regelgevende' handeling is aan te merken. Omdat in dit geval echter uitvoeringsmaatregelen noodzakelijk waren om de aangepaste steunregeling toe te passen, was de tweede mogelijkheid van particulier beroep niet van toepassing. ${ }^{37}$ Het verwijt van het Hof van Justitie aan het

31. Gerecht 16 december 2011, zaak T-202/10, Stichting Woonlinie e.a./ Commissie, ECLI:EU:T:2011:765 en Gerecht 16 december 2011, zaak T-203/10, Stichting Woonpunt e.a./Commissie, ECLI:EU:T:2011:766.

32. Gerecht 16 december 2011, Stichting Woonpunt e.a./Commissie, punten 29-35.

33. Gerecht 16 december 2011, Stichting Woonpunt e.a./Commissie, punten 38-42.

34. HvJ 27 februari 2014, zaak C-132/12 P, Stichting Woonlinie e.a./ Commissie, ECLI:EU:C:2013:335, HvJ 27 februari 2014, zaak C-133/12 P, Woonlinie en Stichting Woonpunt e.a., ECLI:EU:C:2014:105.

35. HvJ 27 februari 2014, Woonlinie en Stichting Woonpunt e.a., punten 46-49.

36. HvJ 27 februari 2014, Woonlinie en Stichting Woonpunt e.a., punten 32-33.

37. HvJ 27 februari 2014, Woonlinie en Stichting Woonpunt e.a., punt 41. 
Gerecht dat het ten onrechte een onderzoek naar het bestaan van een regelgevende handeling had nagelaten kon daarom op twee manieren worden uitgelegd: alleen als een aanmaning om altijd de toepasselijkheid van de laatstgenoemde beroepsmogelijkheid na te gaan of ook als een 'wenk' om een tot een lidstaat gericht besluit van de Commissie tot voorwaardelijke goedkeuring van een algemene steunregeling op te vatten als een regelgevingshandeling.

In de zaken Ferracci en Montessori ${ }^{38}$ heeft het Gerecht de arresten over de wooncorporaties in laatstgenoemde zin opgevat en een tot Italië gericht besluit van de Commissie over een generieke fiscale steunregeling als een regelgevingshandeling gekwalificeerd. Het ging om de vrijstelling van een gemeentelijke onroerende zaakbelasting ten gunste van, heel kort gezegd, allerlei nietcommerciële organisaties die met hun onroerende zaken bepaalde sociale activiteiten uitoefenden. Volgens de Commissie vormde deze vrijstelling onverenigbare staatsteun. Volgens deze instelling was terugvordering van die steun echter volstrekt onmogelijk. Tegen dit besluit stelden Ferracci en Montessori beroep tot nietigverklaring in. Het Gerecht en, in hogere voorziening, het Hof van Justitie verklaarden deze beroepen ontvankelijk omdat een besluit met betrekking tot een nationale steunregeling van algemene strekking is, waarbij werd aangeknoopt aan de definitie die in artikel 1 sub d Verordening (EG) nr. 659/1999 van een steunregeling geeft. ${ }^{39}$

\section{Regelgevende handelingen}

Niet-wetgevingshandelingen van algemene strekking zijn regelgevende handelingen

Zoals opgemerkt was al in eerdere rechtspraak uitgemaakt dat handelingen van algemene strekking van de Unie, met uitzondering van wetgevingshandelingen, als regelgevingshandelingen kunnen worden aangemerkt. ${ }^{40}$ Open was nog de vraag of alle niet-wetgevingshandelingen van de Unie onder het laatstgenoemde begrip vielen. In de zaak Montessori verdedigde de Commissie met kracht dat niet-wetgevingshandelingen en regelgevende handelingen niet identiek waren en dat in ieder geval een besluit met betrekking tot een steunregeling niet als een regelgevende handeling kon worden aangemerkt. Het Hof van Justitie overwoog dat deze interpretatie niet verenigbaar is met het doel van artikel 263, vierde alinea, derde zinsnede VWEU, om de ontvankelijkheidsvoorwaarden te verruimen onder de daarin genoemde voorwaarden. In dat verband verwees het Hof

38. Gerecht 15 september 2016, zaak T-220/13, Scuola Elementare Montesorri/Commissie, ECLI:EU:T:2016:484 en Gerecht 15 september 2016, zaak T-219/13, Ferracci/Commissie, ECLI:EU:T:2016:485

39. Thans Verordening 2015/1589/EU, PbEU 2015, L 248/9.

40. Zie o.m. Gerecht 6 september 2011, zaak T-18/10, Inuit Tapiriit Kanatami e.a./Parlement en Raad, ECLI:EU:T:2011:419, punt 56; Gerecht 21 januari 2014, zaak T-596/11, Bricmate/Raad, ECLI:EU:T:2014:53, punt 65; Gerecht 14 januari 2015, zaak T-507/13, Solarworld e.a./ Commissie, ECLI:EU:T:2015:23, punt 64 van Justitie naar de tekst van de genoemde bepaling, waaruit blijkt dat het begrip regelgevende handeling niet verder is opgesplitst en naar de documenten van de Europese Conventie, waaruit blijkt dat alleen wetgevingshandelingen van dit begrip zijn uitgesloten. ${ }^{41}$ De conclusie is "...dat het begrip "regelgevingshandeling" in de zin van artikel 263, vierde alinea, derde zinsnede, VWEU, alle niet-wetgevingshandelingen van algemene strekking omvat,' aldus de hoogste Unierechter. ${ }^{42}$

$\mathrm{Nu}$ dit vaststaat, kan worden geconstateerd dat kmantitatief gezien het begrip regelgevende handeling zeer omvangrijk is. De categorie van niet-wetgevingshandelingen omvat de volgende groepen handelingen:

1. gedelegeerde verordeningen, richtlijnen en algemene besluiten van de Commissie (art. 290 VWEU); ${ }^{43}$

2. verordeningen, richtlijnen en algemene besluiten van de Commissie op grond van eigen bevoegdheden (zoals art. 106 lid 3 en 108 lid 2 VWEU);

3. uitvoeringsverordeningen, uitvoeringsrichtlijnen en algemene uitvoeringsbesluiten van de Commissie (art. 291 VWEU);

4. verordeningen, richtlijnen en algemene besluiten van de Raad op grond van eigen bevoegdheden (zoals art. 103 en 109 VWEU);

5. uitvoeringsverordeningen, uitvoeringsrichtlijnen en algemene uitvoeringsbesluiten van de Raad (art. 291 VWEU);

6. verordeningen en algemene besluiten van de ECB;

7. handelingen van algemene strekking van andere entiteiten dan instellingen (agentschappen);

8. handelingen van algemene strekking van de Europese Raad. Omdat deze instelling geen wetgevingstaken mag verrichten (art. 15 lid 1 VEU), zijn handelingen van algemene strekking van de Europese Raad per definitie als regelgevende handelingen aan te merken.

Samenvattend is de situatie dat wetgevingshandelingen alleen kunnen worden aangevochten als aan het vereiste van rechtstreeks en individueel raken is voldaan. Zoals eerder opgemerkt is dit een uitzonderlijke situatie. Uiteraard kunnen ook niet-wetgevingshandelingen onder deze voorwaarden worden aangevochten, maar een particulier beroep tot nietigverklaring tegen deze handelingen is ook ontvankelijk in de gevallen waarin deze handelingen als regelgevend (en zonder uitvoeringsmaatregelen) kunnen worden aangemerkt.

Het gebruik van de nieuwe nomenclatuur voor particuliere rechtsbescherming

Het Montessori-arrest bevestigt nog eens dat de Unierechter de nieuwe nomenclatuur van handelingen van de Unie die het Verdrag van Lissabon heeft ingevoerd, ook hanteert om de werkingssfeer van het begrip regel-

41. HvJ 6 november 2018, gevoegde zaken C-622/16 P t/m C-624/16 P, Montessori, ECLI:EU:C:2018:873, punten 25-27.

42. HvJ 6 november 2018, Montessori, punt 28

43. Open is nog de waarschijnlijk theoretische vraag of een gedelegeerde handeling die een wijziging aanbrengt in de tekst van een wetgevingshandeling als een regelgevende handeling moet worden beschouwd. 
gevende handeling en daarmee van de omvang van de particuliere rechtsbescherming te bepalen. Dit geeft aanleiding tot twee samenhangende opmerkingen.

Ten eerste hangt dit onderscheid geheel samen met de plaats en bevoegdheden van het Europees Parlement in de institutionele configuratie van de Unie. Het onderscheid vindt zijn grondslag in twee tegenstrijdige overwegingen. Enerzijds dat de Europese Conventie had aangetoond dat een forse opwaardering van de positie van het Parlement in het institutionele bestel onvermijdelijk was geworden, wat zijn beslag kreeg door de invoering van gewone en bijzondere wetgevingsprocedures. Anderzijds dat met betrekking tot een hele serie onderwerpen de lidstaten toch het regelgevingsmonopolie wilden behouden, met als gevolg dat deze aangelegenheden geen onderwerp van wetgevingsprocedures vormen. Een typisch voorbeeld vormt artikel 43 VWEU over de landbouwpolitiek. De grondslagen van deze politiek (de wijze waarop de landbouwmarkten gereguleerd worden) is een aangelegenheid van de gewone wetgevingsprocedure. De uitwerking daarvan in geldelijke instrumenten (heffingen en subsidies) vormt echter een exclusieve bevoegdheid van de Raad en vindt daarom plaats door niet-wetgevingshandelingen. Dit alles roept de vraag op of dit politieke onderscheid ook geschikt is om de omvang van particuliere rechtsbescherming te bepalen. ${ }^{44}$

De tweede opmerking is dat de rechtsbescherming die het beroep tot nietigverklaring tegen regelgevende handelingen biedt, geheel afhankelijk is van de vorm van de aangevochten handeling. Als een maatregel die geen uitvoeringsmaatregelen vereist, bijvoorbeeld een verbod van een bepaalde gedraging, vervat is in een wetgevingshandeling, staat daartegen geen beroep tot nietigverklaring open. Dit is wel het geval als dat verbod is vervat in een niet-wetgevingshandeling. De omvang van particuliere rechtsbescherming onder de derde zinsnede is nu afhankelijk van de vorm van de aangevochten handeling en daardoor, binnen bepaalde grenzen, ook van de wil van de auteur van die handeling. Voor de regelgever van de Unie kan dit aanleiding vormen om bijvoorbeeld geboden en verboden (die geen uitwerking vereisen) neer te leggen in een wetgevingsverordening van Parlement en Raad in plaats van een gedelegeerde verordening van de Commissie. De conclusie is dat gezien vanuit het oogpunt van particuliere rechtsbescherming twee gelijke situaties ongelijk behandeld worden. Hoe valt een dergelijk onderscheid te verenigen met artikel 47 Handvest? Daarbij moet ook worden opgemerkt dat de omschrijving van een verordening in artikel $288 \mathrm{VWEU}$ uitdrukkelijk geen onderscheid maakt tussen wetgevings- en niet-wetgevingsverordeningen. De uitlegging van de vereisten voor de ontvankelijkheid van een nietigheidsberoep vond tot nu toe steeds plaats aan de hand van objectieve criteria, afgeleid uit de inhoud van de maatregel, zoals blijkt uit de jurisprudentie over het begrip voor beroep vatbare handeling, procesbelang en de aangestipte rechtspraak over rechtstreeks en individueel raken.

Uiteraard kan men aanvoeren dat het Hof van Justitie de wil van de verdragsgevers is gevolgd, zoals die blijkt uit de travaux préparatoires. Maar is, als het gaat om particuliere rechtsbescherming, de wil van de verdragsgevers de enige maatstaf? In zoverre reflecteert de rechtspraak over de afbakening van het begrip regelgevende handeling niet de geest van het Van Gend ES Loos-arrest. ${ }^{45}$

Individuele besluiten met een algemene strekking Het begrip 'besluit' in artikel 288 VWEU heeft betrekking op het geval waarin de Unie ingrijpt in de rechtspositie van de adressant daarvan. Laatstgenoemde kan daartegen altijd beroep tot nietigverklaring instellen. Qua inhoud kan een verschil worden gemaakt tussen een besluit dat betrekking heeft op één specifiek geval (zoals het opleggen van een sanctie, het al dan niet toekennen van een subsidie, vergunning voor het in de handel brengen of het al dan niet goedkeuren van steun aan een onderneming, enzovoort) en een besluit waarvan de inhoud van algemene aard is.

De eerste categorie van besluiten kan zowel lidstaten als particulieren betreffen. Deze besluiten houden vrijwel steeds de toepassing in van een algemene regeling op een individueel geval, zoals bij de bepalingen over steunmaatregelen en concurrentie. Daarom kan ook wel worden gesproken over individuele of administratieve besluiten. Volgens artikel 263, vierde alinea, tweede zinsnede VWEU, kunnen derden tegen die besluiten alleen opkomen als zij daardoor rechtstreeks en individueel geraakt zijn. Deze besluiten vallen niet onder het begrip regelgevende handeling omdat zij niet van algemene strekking zijn. ${ }^{46}$

De tweede categorie van besluiten is van algemene strekking omdat de werkingssfeer is omschreven aan de hand van objectieve factoren en de rechtsgevolgen daarvan een op algemene en abstracte wijze omschreven groep van personen betreffen. In het Montessori-arrest ging het om een besluit van de Commissie over een steunregeling. Handelingen van dit type vindt men ook in de sectoren landbouw, vervoer, telecommunicatie en onder de gemeenschappelijke handelspolitiek. Omdat een dergelijk besluit een adressant heeft, zou men kunnen betogen dat er geen sprake is van een handeling van algemene strekking en dus ook niet van een regelgevende handeling. In de rechtspraak is deze conclusie nooit aanvaard. Bepalend voor de kwalificatie van die besluiten is de inhoud daarvan. Daarom hebben volgens vaste rechtspraak besluiten van de Commissie over steunregelingen een algemene strekking. ${ }^{47}$ Onder de
44. Zie ook M.A. Dauses, 'Effektiver Rechtsschutz in Gefahr? Ein Nachtrag zum Klagerecht Privater gegen Gesetzgebungsakte', Europäische Zeitschrift für Wirtschaftsrecht 2014, p. 121 en F.-V. Guiot, 'L'affaire Inuit: une illustration des interactions entre recours individuel et équilibre institutionnel dans l'interprétation de l'article 263 du TFUE', Revue trimestrielle de droit européen 2014, p. 389.
45. HvJ 5 februari 1963, zaak C-26/62, Van Gend \& Loos, ECLI:EU:C: 1963:1.

46. HvJ 17 september 2015, zaak C-33/14 P, Mory e.a./Commissie, ECLI:EU:C:2015:609, punt 92; HvJ 10 oktober 2017, zaak C-640/16 P, Greenpeace Energy/Commissie, ECLI:EU:C:2017:752, punt 26.

47. HvJ 6 november 2018, Montessori, punt 31 
tweede zinsnede van de vierde alinea van artikel 263 VWEU kunnen derden tegen die besluiten alleen opkomen als zij daardoor rechtstreeks en individueel zijn geraakt. Vanwege de algemene strekking van die besluiten zal aan dit ontvankelijkheidsvereiste maar zelden kunnen worden voldaan. Het nieuwe van het Montesso$r i$-arrest is dat ook deze besluiten, op grond van hun algemene strekking, als regelgevende handelingen worden aangemerkt, waardoor het vereiste van individueel raken niet van toepassing is. In het geval van steunmaatregelen is consequentie wel dat derden tegen een besluit over individuele steunverlening moeilijker kunnen opkomen dan tegen een besluit over een steunregeling. Dit is op zijn minst merkwaardig te noemen.

\section{Geen uitvoeringsmaatregelen}

Is het Montessori-arrest 'revolutionair', zoals in een eerste reactie werd gesteld? ${ }^{48}$ Dat is niet zo. Hoe breed of eng het begrip 'regelgevende handeling' ook wordt uitgelegd, altijd moet aan de voorwaarde zijn voldaan dat de toepassing daarvan geen uitvoeringsmaatregelen met zich meebrengt. In het genoemde arrest is deze voorwaarde nog eens met kracht herhaald. ${ }^{49}$ Volgens de rechtspraak vloeit dit vereiste rechtstreeks voort uit het doel van de clausule over de regelgevende handelingen om te voorkomen dat om rechtsbescherming te verkrijgen, de particulier eerst de voorschriften daarvan moet overtreden. Zijn er wel uitvoeringsmaatregelen, dan is rechtsbescherming door de nationale rechter gegarandeerd. ${ }^{50}$

Handelingen van de Unie van algemene strekking vereisen echter vrijwel altijd uitvoeringsmaatregelen van de Unie en/of van de lidstaten. Die omstandigheid vormt ook de bestaansgrond voor artikel 291 VWEU. Vergunningensystemen, subsidieregelingen en heffing van bedragen om het gedrag van marktdeelnemers te sturen zijn nauwelijks voorstelbaar zonder individuele uitvoeringsmaatregelen. Hetzelfde geldt voor beperkende maatregelen tegen personen en entiteiten. Anders gezegd, de derde zinsnede is alleen van betekenis voor gevallen waarin een niet-wetgevingshandeling voorziet in rechtstreeks toepasselijke plichten en verboden. Ook het Montessori-arrest illustreert dat het ontbreken van uitvoeringsmaatregelen uitzonderlijk is. Niet-terugvordering van onrechtmatige steun vereist geen uitvoeringsmaatregelen, ${ }^{51}$ maar een dergelijk besluit van de Commissie is toch zeldzaam.

Daarbij komt ook de omstandigheid dat in de rechtspraak het vereiste van geen uitvoeringsmaatregelen letterlijk en dus strikt wordt uitgelegd. ${ }^{52}$ De toepassing van een regelgevende handeling op de situatie van de klager

48. Zie het redactioneel van Th. Jaeger, 'The Court's Paradoxical Montessori Revolution', European State Aid Law Quarterly 2018, p. 471.

49. HvJ 6 november 2018, Montessori, punt 58.

50. HvJ 19 december 2013, zaak C-274/12 P, Telefónica/Commissie, ECLI:EU:C:2013:852, punt 27; Gerecht 2 juni 2016, zaak T-160/13, Bank Mellat/Raad, ECLI:EU:T:2016:331, punt 48.

51. HvJ 6 november 2018, Montessori, punt 62.

52. Zie voor kritiek op deze interpretatie J. Wildemeersch, 'L'article 263, alinéa 4, du traité FUE: une modification des conditions de recevabilité du recours en annulation sans (véritables) conséquences', in: S. Mahieu mag geen enkele uitvoeringsmaatregel van de Unie of van de lidstaten vereisen of toestaan omdat die maatregelen voor de Unierechter of voor de nationale rechter kunnen worden aangevochten. ${ }^{53}$ Dit vormt het grote verschil tussen 'geen uitvoeringsmaatregelen' en rechtstreeks raken in de tweede zinsnede. Aan het laatste vereiste is volgens de rechtspraak ook voldaan als de nationale uitvoeringsmaatregel van automatische aard is en de lidstaat geen juridische of feitelijke marge heeft bij het aannemen van die maatregel.

\section{Slotopmerkingen}

Met betrekking tot particuliere rechtsbescherming tegen rechtshandelingen van de Unie is en blijft de hoofdregel dat op grond van artikel 263, vierde alinea, VWEU, maatregelen van algemene strekking niet vatbaar zijn voor beroep tot nietigverklaring. De voorwaarde van rechtstreeks en individueel raken vormt daarop slechts een uitzondering van beperkte betekenis. Ook de derde zinsnede van deze alinea, ingevoegd door het Verdrag van Lissabon, brengt in de rechtsbescherming van particulieren tegen handelingen van algemene strekking geen wezenlijke verandering. Wetgevingshandelingen zijn zonder meer van het begrip regelgevende handelingen uitgesloten. De voorwaarde van het niet meebrengen van uitvoeringsmaatregelen reduceert de derde zinsnede tot een pure uitzondering. Dit vereiste blijft echter noodzakelijk om de bevoegdheidsverdeling die de verdragen aanbrengen tussen de Unierechter en de nationale rechter te respecteren. De conclusie is dat zolang de rechtspraak de nomenclatuur van handelingen van de Unie ook hanteert om de werkingssfeer van de derde zinsnede van artikel 263, vierde alinea, VWEU, te bepalen, een wezenlijke verandering van de particuliere rechtsbescherming in het kader van het beroep tot nietigverklaring is uitgesloten.

Is er een alternatief? De vraag is of de rechtspraak zich wel voldoende rekenschap geeft van de plaats en de inhoudelijke betekenis van het Handvest voor de particuliere rechtsbescherming. Zoals eerder opgemerkt heeft het Hof van Justitie zich steeds op het standpunt gesteld dat de ontvankelijkheidsvoorwaarden van het nietigheidsberoep door artikel $47 \mathrm{Hv}$ niet veranderd zijn. Iets anders is echter dat als een particulier stelt dat een maatregel van algemene strekking van de Unie hem in een door het Handvest gegarandeerd grondrecht aantast (stelplicht) en dit gemotiveerd aannemelijk maakt (bewijsplicht), aan het vereiste van individueel raken zou kunnen zijn voldaan. Omdat thans de grondrechten als de bestaansgrond van de Unie worden gezien, zoals onder meer blijkt uit artikel 2 VEU en de rechtspraak, zou men kunnen stellen dat een inbreuk op een grondrecht de particulier per definitie individueel raakt. Deze rechtsbeschermingsfiguur, die bestaat in een aantal lid-

(red.), Contentieux de I'Union européenne: questions choisies, Brussel: Larcier 2015, p. 155.

53. HvJ 6 november 2018, Montessori, punten 63-64. 
staten (o.a. Duitsland, Spanje), is ook in het Unierecht niet onbekend. Artikel 263, eerste alinea, VWEU, kent de ECB, de Rekenkamer en het Comité van de Regio's het recht toe om door een nietigheidsberoep hun prerogatieven in het besluitvormingsproces veilig te stellen. Daartoe is voldoende als de betrokken instantie stelt en uiteenzet dat een dergelijk prerogatief wezenlijk is miskend. ${ }^{54}$ Misschien ligt hier een onderwerp voor een proefschrift!

54. Zie HvJ 20 oktober 1992, zaak C-295/90, Parlement/Raad, ECLI:EU:C: 1992:294, punt 27; HvJ 2 maart 1994, zaak C-316/91, Parlement/ Raad, ECLI:EU:C:1994:76, punt 12; HvJ 13 juli 1995, zaak C-156/93, Parlement/Commissie, ECLI:EU:C:1995:238, punt 11. 